\title{
Lifestyle Patterns During the Covid-19 Pandemic
}

\author{
(Especially for Bandung Raya)
}

\author{
Adhika Bergi Nugroho*, Nanda Ravenska, Pepi Zulvia \\ Polytechnic of STIA LAN \\ Bandung, Indonesia \\ *adhika.bergi@gmail.com, nandaravenska@gmail.com, pepizulvia17@gmail.com
}

\begin{abstract}
The pandemic that occurred in early 2020 forced people to adapt to the new normal. When people are faced with this situation, many things change and can be seen from their lifestyle, including in purchasing staples or interacting with each other. In the locus of Indonesian society, especially in Bandung Raya, which is the most populous province in Indonesia, this change in behavior can represent the lifestyle of Indonesian society in general. Starting from awareness of a lifestyle that is in accordance with the covid-19 virus prevention protocol and also the level of public anxiety about shopping as needed. In this paper, we can see a summary of changes in the behavior and lifestyle of people, especially Bandung Raya representing Indonesian society, and this paper can be a reference in determining product, service, and even policy strategies according to the needs of the Indonesian people.
\end{abstract}

Keywords—pandemic 2020, lifestyle, Bandung Raya

\section{INTRODUCTION}

Covid-19 began to appear in December 2019 in Wuhan City, China. Covid-19 is an infectious disease caused by a type of corona virus (who.int). The trend of the spread of Covid-19 continues to increase and spreads to various countries, including Indonesia. See figure 1 below.

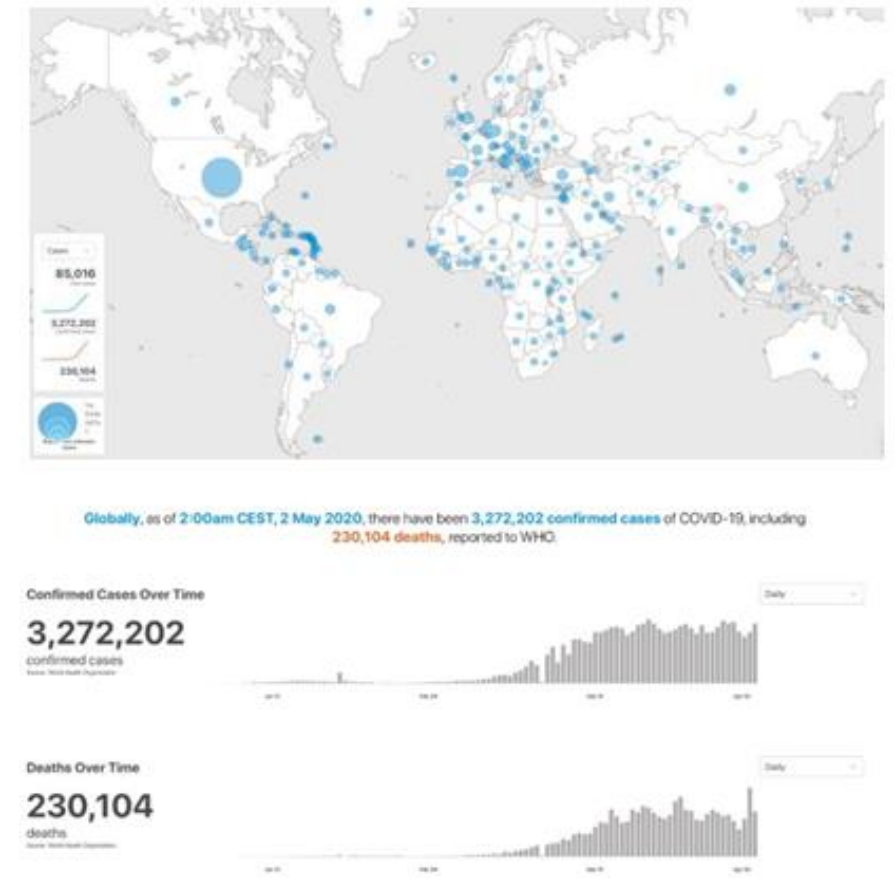

Fig. 1. Global development of Covid-19 (source: WHO).

The first case of Covid-19 in Indonesia was known at the end of February 2020. Since then, until this research was conducted in early May 2020, the trend of Covid-19 cases in Indonesia has increased. On May 2, 2020, 10,843 positive cases were detected, 1,665 patients recovered, and 831 patients died due to Covid-19 in Indonesia. This data based on covid19.go.id, access at 13:35 WIB on May 3, 2020.

Seeing the increasing trend of positive cases, especially in Indonesia, the Indonesian government has initiated a "di rumah saja (Stay at home)" campaign to break the chain of the spread of Covid-19. So that many activities are changed and proposed to be carried out from home. Like office employees, they do not need to go to the office and start working from home or it is called WFH (work from home). In addition, several local governments have also set "PSBB" (Large-Scale Social Restrictions) rules according to the direction from President and with the permission of the Ministry of Health which refers 
to Government Regulation Number 21 of 2020 concerning Large-Scale Social Restrictions in the Context of Accelerating Handling of Corona Virus Disease 2019 (COVID-19).

Based on survey results invent.ure, many businesses will decline and there will increase during the lifestyles "at home" is applied. For example, the hospitality industry, transportation, malls, restaurants/cafe, oil \& gas, automotive, sports venues, etc. are likely to decline from an economic perspective. On the other hand, the logistics industry, grocery stores, e-commerce, media \& telco, telemedicine, etc. tend to increase. See figure 2 below.

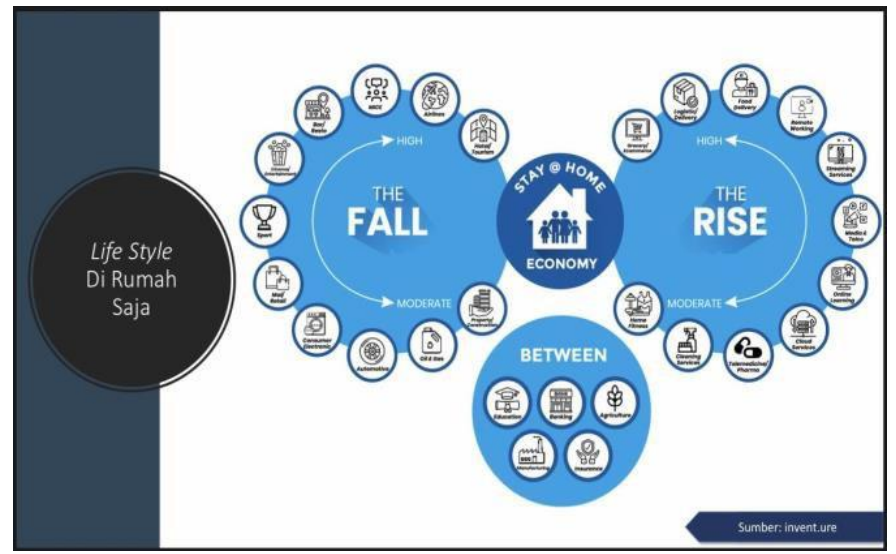

Fig. 2. Businesses that are affected by the lifestyle at home only.

Based on the results of a survey by Kantar Indonesia, almost $80 \%$ of Indonesians spent their time at home during the Covid-19 pandemic. The activities carried out are various, ranging from watching $\mathrm{TV}$, cooking, reducing the intensity of going out of the house, working online, studying online and other activities that can still be done at home including shopping for basic necessities that can be done online through e-commerce such as Tokopedia, Shopee, klikindomaret, yogyaonline, etc.

Before shops selling non-staple goods were closed, many people preferred to shop online along with the increasing number of Covid-19 cases. Here are some of the performances and transactions that e-commerce booked during the pandemic based on excerpts from the Oxford Business Group press release. Bukalapak, one of five unicorn start-up companies in Indonesia with a valuation of US \$ 1 billion, has expanded its choice of basic food products over the past few weeks to meet the needs of consumers who stay at home. The increase in transactions on the e-commerce platform was accompanied by an increase in new users due to a shift in the MSME business model and changes in consumption behavior.

Separately, Blibli revealed that sales of basic food products, cleaners, sanitizers, health masks and vitamins have increased over the past few weeks. The e-commerce company also posted an increase in demand for cooking utensils, video games and sports equipment as Indonesians began to adjust to spending time at home. On the other hand, the demand for smartphones, automotive products, shoes, formal wear, and holiday tickets has decreased due to uncertain economic conditions and health concerns so that people have begun to reduce unnecessary consumption.

E-commerce has been able to attract many consumers in Indonesia even before the Covid-19 outbreak. E-commerce is also one of the main drivers that make Indonesia the country with the largest digital economy value in Southeast Asia reaching \$ 40 billion in 2019 and is projected to increase to \$ 130 billion by 2025 . With more and more retail stores and consumers forced to switch to e -commerce, its growth can be further enhanced. Before Covid-19, e-commerce was just an option. But for now, it is very important for retail stores and manufacturers to sell products through e-commerce platforms to be able to maintain their business. This will have a positive long-term impact as consumers will get used to shopping online. See figure 3 below.

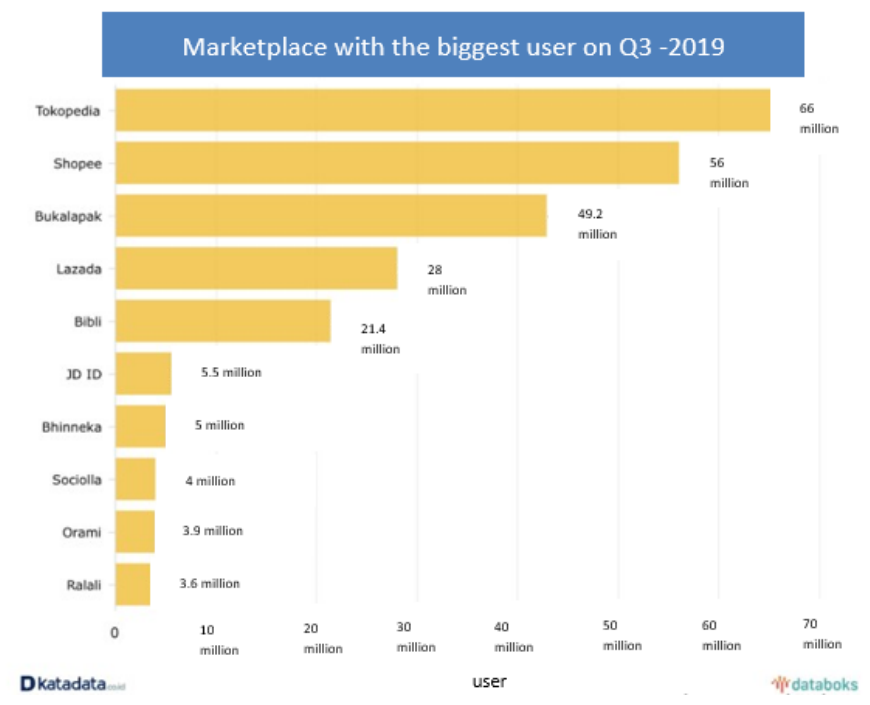

Fig. 3. Data on e-commerce visitors before the Covid-19 pandemic (Source: Katadata).

The PSBB had made people worried about meeting their basic needs, causing a panic buying effect. During the PSBB period, several industries continued to operate, such as the logistics industry, so that the distribution of goods continued. People can still make purchases online through e-commerce.

Yogyaonline and klikindomaret are e-commerce services that provide all necessities. Consumers can make transactions online and the goods will be delivered to the consumer's place. Through this research, we will look at consumer purchasing decisions in meeting basic needs.

Based on the above background, the problems to be examined in this study can be seen as follows:

- What is the lifestyle pattern of community activities before and during the Covid-19 pandemic?

- Does this lifestyle pattern affect people's spending during the Covid-19 pandemic? 
- What is the lifestyle pattern during the Covid pandemic 19 ?

\section{LITERATURE REVIEW}

\section{A. Buying Lifestyle}

The government has issued a policy to prevent the spread of Covid-19. One of the popular policies in society is Large-Scale Social Restrictions (PSBB). Bandung Raya has implemented the PSBB since one and a half months the first Covid-19 case appeared in Indonesia. This PSBB is carried out periodically when the people of Bandung Raya are having a long holiday which may cause a large crowd of residents. Initially this PSBB did not allow restaurants and malls to open, but after the third PSBB ended in May, the restaurant dam Mall was allowed to reopen but within a certain period of time every day, from 10 to $7 \mathrm{pm}$.

However, after the implementation of the PSBB for approximately 2 months, the public has become very familiar with shopping that is done online, starting from basic goods, ordering food, and also fashion items. For most residents of Bandung Raya, shopping online is a common thing to do, but for some consumers shopping may become uncontrollable obsession [1], especially if anxiety arises due to the limited space for the community because of PSBB in the city of Bandung Raya.

Underlying anxiety or tension. The resulting purchasing behavior may lead to social, family, and financial problems [2]. Based on this research we wanted to see if Bandung Raya residents had the same tendency, and what solutions could help lead them to adopt a more positive lifestyle. So that respondents are selected from among families and housewives where in the family there are fathers, mothers, small children to adolescents, with the hope of knowing their lifestyle in adapting to the new normal.

\section{B. Digital Marketing}

Currently digital marketing content is increasingly advanced, initially digital marketing only focused on the promotion of a product advertised by the website [3]. But now digital marketing has entered into social media which is accessed by its users every day. This also makes marketing through digital marketing more effective because it is supported by artificial intelligence.

This artificial intelligence will enable digital marketing content in this case, namely promotion becomes easier. For example, if a user uses social media to find a new hour, less than an hour after that the user is still or will be accessing social media, an advertisement for the clock (product) will appear according to his desire [4]. This will indirectly suggest consumers to buy the product they want. In a pandemic like this, people will tend to stay at home more often so they will access digital content more often, one of which is social media. so that the existence of digital marketing will greatly affect consumer behavior.

\section{METHODS}

This research is based on quantitative and survey-based studies with a conceptual framework designed to see the extent to which changes in community behavior patterns, especially the Greater Bandung area during the COVID-19 pandemic. Therefore, this study captures two sides to the behavior patterns before the pandemic and during the pandemic until now (when the survey was conducted).

\section{A. Method and Participant Characteristic}

Data were collected using a questionnaire distributed by Non-Probability Sampling (Combine Convenience, Voluntary and Snowball Sampling). Respondents who were obtained until the end mostly women $(77.59 \%)$ while other $(22.41 \%)$ are men. With a percentage of $43 \%$ represented by jobs as housewives (IRT), students, contract workers, retirees, est.

The average age of respondents for the Bandung Raya area is around 18-30 years which can be categorized as the millennial generation who are literate with technological advance. If seen from the characteristics of the respondents, the average income they earn per month is Rp. 1.000.000 - Rp. 3.000.000 which means that the respondents obtained are in the middle to lower economy. See figure 4 below.

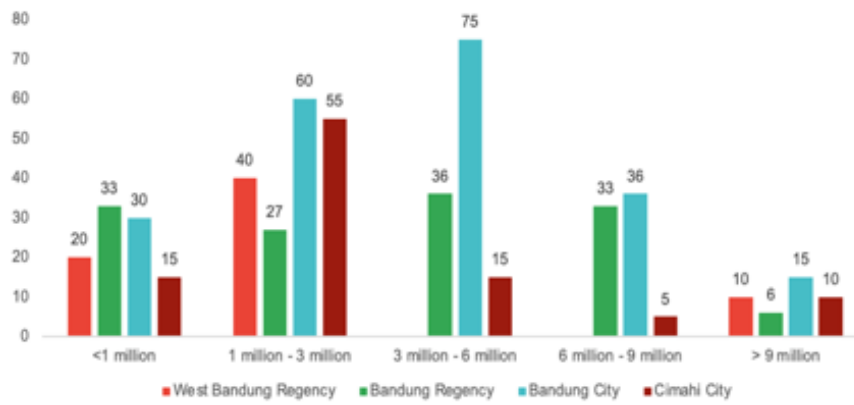

Fig. 4. Average Income per Month

\section{B. Data Analysis}

In knowing the behavior patterns of community activities before and during the Covid-19 Pandemic, this research looked at the data accumulation index obtained. Measuring this behavior pattern is also described in a descriptive quantitative way as a form of representing changes in people's attitudes before and during the Covid-19 pandemic.

\section{RESULTS AND DISCUSSION}

To find out the behavior patterns of community activities before and during the Covid-19 Pandemic, this research begins by looking at the reaction of the community in responding to the conditions of the COVID-19 Pandemic. The results obtained illustrate that on average, the people of Bandung Raya acted naturally (correctly / proportionally) in responding to the Covid-19 Pandemic. See figure 5 below. 


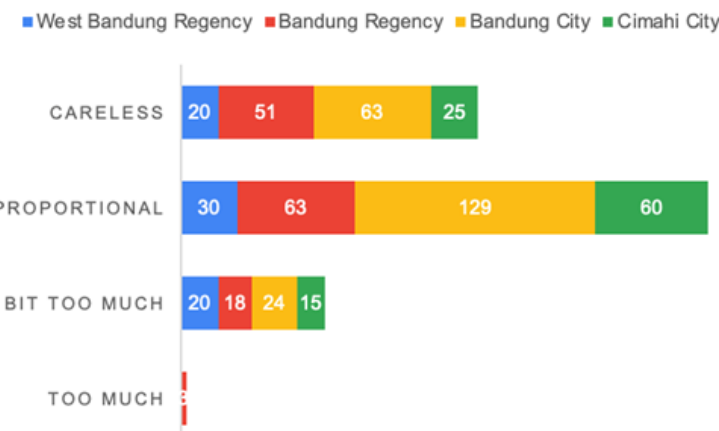

Fig. 5. People's reaction to the conditions COVID-19 Pandemic.

In line with the public's reaction, it can be accepted that the psychological condition of the community in facing news of the emergence of the Covid-19 pandemic is influential $(47.22 \%)$. Generally, this psychological condition has an influence on changes in the behavior patterns of the people of Bandung Raya which are felt to have implications for people's daily habits. See figure 6 below.

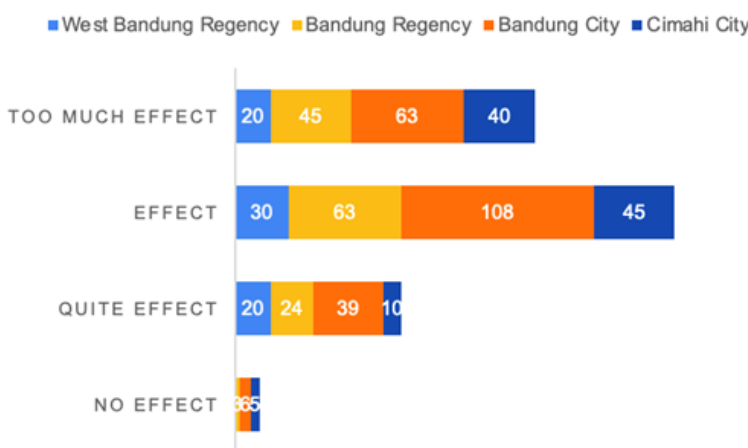

Fig. 6. Psychological conditions facing news of the emergence of the Covid19 Pandemic.

This psychological condition has an impact on changing people's behavior patterns in shopping during the Covid-1 Pandemic. Every area in Bandung Raya, people's behavior in shopping has increased significantly, especially in buying basic needs $(33 \%)$, pulses / data packages $(25 \%)$, health (medicine, vitamins and sanitation) (20.25\%), etc. This is thought to be due to the effect of the public's fear of rising prices and difficulty accessing outside the house during the Covid-19 pandemic. However, limitations during a pandemic have a good effect on changes in people's behavior to be technology literate. The shopping method that is usually done conventionally is slowly changing to an online method. See figure 7 below.

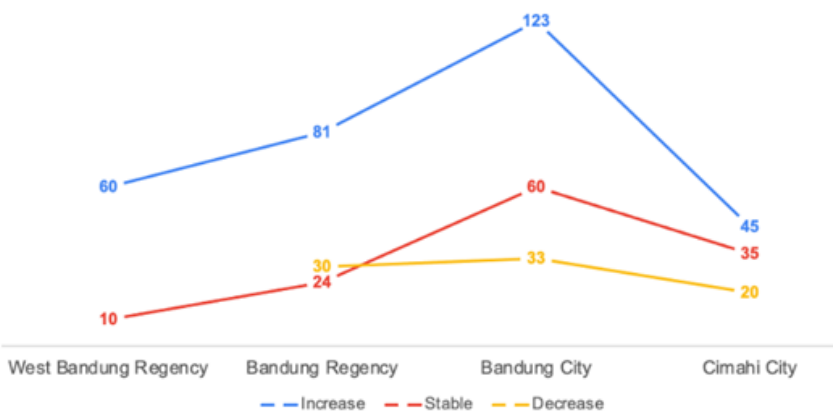

Fig. 7. Online shopping during Covid-19 Pandemic.

It can be seen that changes in people's behavior in shopping online have greatly increased in Bandung, although on average each region has experienced an increase. This situation suggests that access to online shopping in Bandung is easier than for people in other areas. The habits of Bandung people are also felt to be more up to date in accessing information for online shopping.

Based on the survey results obtained, people's lifestyle, especially in shopping, has changed. In Figure 8, the conditions before and during the Covid-19 pandemic are presented. It can be said that the behavior and lifestyle patterns of urban communities have changed since the Covid-19 Pandemic compared to district areas. Behavior in shopping both online and offline makes their needs increase, especially in meeting their daily needs (especially staples).

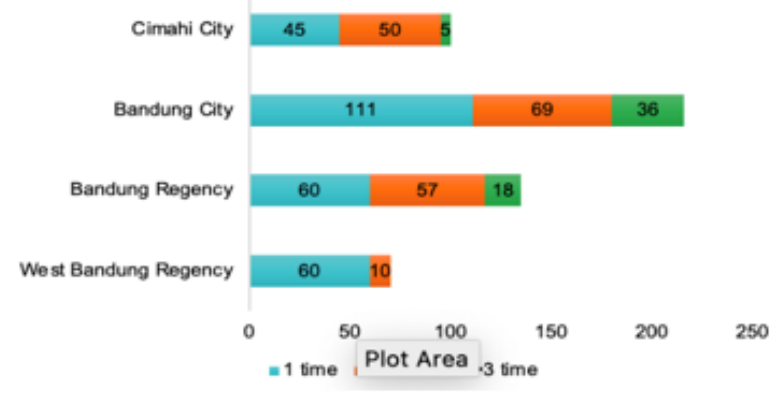

(a)

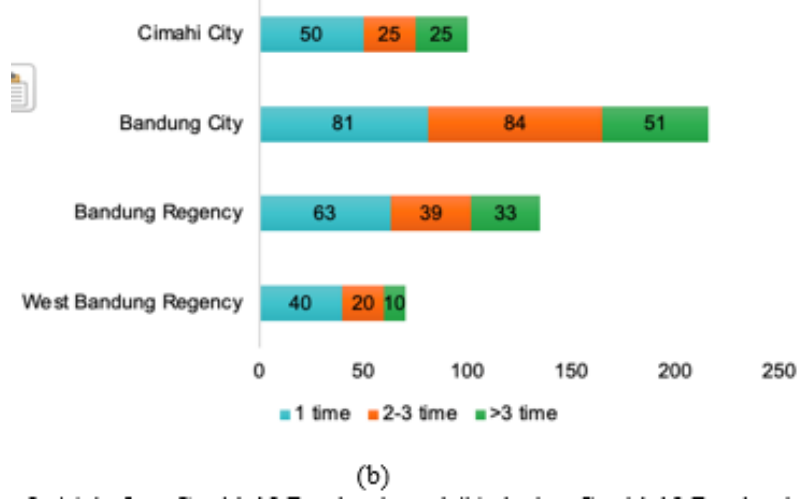

Fig. 8. (a) before Covid-19 Pandemic and (b) during Covid-19 Pandemic. 
Figure 8 shows the lifestyle patterns of urban people, especially the city of Bandung (note the red color) illustrates that people living in the city of Bandung have made it a habit to adjust to the conditions during the Covid-19 pandemic. Although in general the increase in shopping in each region has also increased.

In the accumulated measurements obtained, the impact of the Covid-19 pandemic has an influence on the lifestyle patterns of the people in Bandung Raya. The presentation of the data presented illustrates this lifestyle pattern in line with technological advances (change from offline to online) and is also related to where they live. Meeting needs during a pandemic cannot be reduced in their daily activities. Although the space for people to move around is still limited, changes in people's lifestyles are also felt to be more flexible.

\section{CONCLUSION}

The pattern of people's behavior in responding to the situation before and during Covid-19 has psychologically changed. Along with that, it makes people's lifestyle patterns also influence. This can be seen from the shopping style of the community that has moved from offline to online to an increase in activity in shopping itself. The accumulated answers of respondents also found a comparison of lifestyle patterns in cities and regencies, where people's shopping activities in cities tend to increase when compared to activities carried out by people in the district.
The lifestyle patterns in this research are just reflected in the answers given by the respondents. There needs to be further research related to this lifestyle pattern with the income generated by the community, both city and district.

\section{ACKNOWLEDGMENT}

Thank you to the STIA LAN Bandung Polytechnic, especially the public sector business administration study program, which has provided the opportunity for our research team to be allowed to carry out research according to the topics we are interested in. And also thanks to everyone who has pleased us to interview and ask questions regarding lifestyle and shopping behavior during this pandemic. Hopefully we can present to you the results of our research and can be used as a reference in your decision making.

\section{REFERENCES}

[1] R.J. Harnish, K.R. Bridges, and J.L. Karelitz, "Compulsive Buying: Prevalence, Irrational Beliefs and Purchasing," International Journal of Mental Health and Addiction, vol. 15, no. 5, pp. 993-1007, 2016.

[2] T.C. O'Guinn and R.J. Faber, "Compulsive buying: A phenomenological exploration," Journal of Consumer Research vol. 16, no. 2, pp. 147-157, 1989.

[3] S. Gurnelius, 30-minute Sosial Media Marketing. USA: McGraw- Hill Co, 2011.

[4] J.A. Roberts and E. Jones, "Money Attitudes, Credit Card Use, and Compulsive Buying among American College Students," Journal of Consumer Affairs, vol. 35, no. 2, pp. 213-240, 2001 